\section{Trivialkunnskap om mikrober for spesielt interesserte}

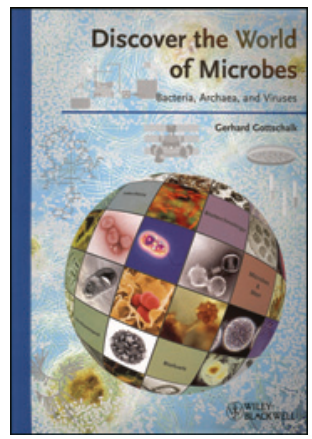

Gerard Gottschalk

Discover the world of microbes

Bacteria, archaea and viruses. 400 s, tab, ill.

Chichester: Wiley-Blackwell, 2012.

Pris GBP 45

ISBN 978-3-527-32845-1

\section{Raskt sveip gjennom mikrobenes verden}

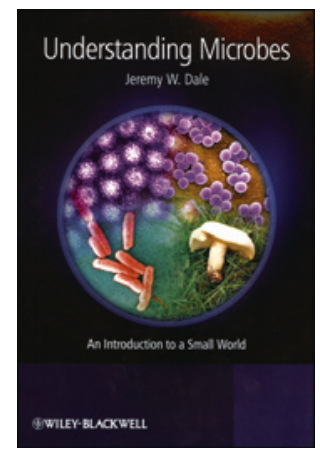

Jeremy W. Dale

\section{Understanding microbes}

An introduction to a small world. 230 s, ill.

Chichester: Wiley-Blackwell, 2013.

Pris GBP 23

ISBN 978-1-1199-7879-4
Forfatteren er den anerkjente professoren og mikrobiologen Gerard Gottschalk. I omtalen angis det at boken dekker hele det mikrobiologiske spekteret, altså ikke bare den medisinske mikrobiologien, men også andre relevante, mindre relevante og kuriøse sider av mikrobiologien. Det kommer ikke klart frem hvem målgruppen erstudenter, legfolk, spesialister?

Layouten er behagelig, med en fin inndeling og fargerike, relevante og informative figurer. Boken er todelt, med en lesedel på 256 sider og en studieguide på 87 sider. Studieguiden er ment som et supplement til lesedelen dersom man ønsker litt mer bakgrunnsinformasjon. I tillegg er det et appendiks med ordforklaringer.

Språket er svært godt, og Gottschalk har åpenbart gjort grundig arbeid for å gjøre tidvis vanskelige emner og tørt stoff spennende og interessant. Det er ingen tvil om at dette faget fascinerer ham voldsomt, og hans entusiasme er velformulert og smittende. Boken er bygd opp som en samtale mellom forfatteren selv og en fiktiv person som har interesse for emnet uten å være ekspert. Dette er gjort for å holde teksten på et jordnært plan. Og det fungerer svært godt - du blir nærmest tatt med på en studiereise sammen med forfatteren til forskjellige plasser rundt om i verden og til ulike tidsepoker i jordens historie - i den hensikt å skape begeistring for, og forståelse av, mikrobers plass i verden.

Forfatteren tar for seg mange emner innen mikrobiologien: basal cellebiologi, evolusjon, livets opprinnelse, klimaproblemer og mer trivielle, hverdagslige emner som alkohol- og osteproduksjon. Boken er på 400 sider, og da sier det seg selv at dette er altfor kort til å kunne gi en grundig innføring $\mathrm{i}$ «hele spekteret». Spesielt har den mangler når det kommer til den medisinske mikrobiologien det er rett og slett ikke viet nok plass til dette om man ønsker å benytte den som en lærebok i medisinsk mikrobiologi. Rent medisinsk sett er kun korte kapitler viet emner som resistens, diagnostiske prinsipper og antibiotika. Her er det noe nyttig informasjon å hente, men om man primært ønsker å lære om medisinsk mikrobiologi, finnes det andre, mye mer passende bøker på markedet.

Dette er en bok som fenger en interessert leser, og den kan fint leses fra perm til perm. Som oppslagsverk fungerer den heller dårlig. Jeg kan ikke anbefale boken som en innføring i mikrobiologi sett utelukkende fra et medisinsk perspektiv. Boken fremstår nærmest som en «trivialkunnskapsbok» om mikrober for spesielt interesserte. Den vil derfor kunne glede en leser med interesse for mikrobiologi som ønsker å lære mye om mikrober utenom den medisinske sfæren.

\section{Øystein Sverdrup}

Diagnostisk klinikk, mikrobiologisk fagområde

Nordlandssykehuset Bodø
Vår forståelse av mikrobiologi er gjennom de siste tiårene blitt revolusjonert av nyvinninger innenfor molekylærbiologi og mikroskopiteknikker. I medisinsk sammenheng får vi et stadig bedre bilde av hvordan mikrober omgir oss og påvirker oss både ved sykdom og helse. Men mikrobenes rolle i naturen strekker seg selvfølgelig langt utover det som er knyttet til menneskene og vår eksistens. Mikrober er sentrale aktører i naturens mange kretsløp og har derfor fătt fornyet interesse $\mathrm{i}$ forbindelse med forurensning og klimaendringer. I vår utforskning av verdensrommet er vi stadig på jakt etter tegn til mikroskopisk liv på andre planeter.

Alt dette og mer til er tema for Understanding microbes An introduction to a small world. I de ti kapitlene tar forfatteren for seg grunnleggende oppbygging og funksjon av mikrober og immunsystem, historiske og aktuelle epidemier, i tillegg til forebygging og behandling av infeksjonssykdommer. Videre diskuterer forfatteren hvordan vi kan nyttiggjøre oss mikrober i næringsmiddelindustri, bioteknologi og regulering av prosesser i naturen.

Enkelte bilder finnes, men generelt er illustrasjonene sparsomme. Det er ingen tabeller og kun et fåtall figurer. Språket er lett tilgjengelig og uformelt, selv om stoffet er komplisert. Det gis ingen kildehenvisninger eller referanser til videre lesning.

Popularisering av vitenskapelig stoff er en krevende øvelse, og forfatteren har kun delvis lyktes i sin ambisjon. Uten forkunnskaper vil informasjonsmengden være vanskelig å overkomme, og for lesere med interesse for feltet kan presentasjonen virke overfladisk og upresis. Illustrasjoner og tabeller kunne med fordel ha erstattet en del av teksten. De aller fleste eksemplene er hentet fra Storbritannia, hvilket gir boken et lokalt preg når den tar mål av seg til å behandle store globale spørsmål. Forfatteren ønsker åpenbart å nå utenfor sitt eget fagmiljø, og boken er heller ikke strukturert som en lærebok for formell utdanning. Den kan derfor fortrinnsvis anbefales som populærvitenskapelig sommerlektyre for den som er nysgjerrig av natur, og som ønsker en kjapp introduksjon til alt det som lever og rører på seg, rundt oss og inni oss.

Gunnar Skov Simonsen

Avdeling for mikrobiologi og smittevern

Universitetssykehuset Nord-Norge 